\title{
Increased Use Value of Coffee Bean Skin Waste as Liquid Fertilizer in Sukorambi Jember Area
}

\author{
${ }^{1}$ Nur Faizin, ${ }^{2}$ Meta Fitri Rizkiana, ${ }^{3}$ Haeruddin \\ ${ }^{1,3}$ Civil Engineering Department, Faculty of Engineering, University of Jember \\ ${ }^{2}$ Chemical Engineering Study Program, Mechanical Engineering Department, Faculty \\ of Engineering, University of Jember
}

\begin{abstract}
The Faculty of Engineering's community service program, University of Jember, with a partner, the Sumber Kembang Kelompok Tani (Farmer Group), aims to overcome partner problems, about the accumulation of coffee bean skin waste that is not utilized. So far, the Sumber Kembang Kelompok Tani (Farmer Group) has not utilized coffee waste properly. The waste of the coffee bean skin will be processed into liquid fertilizer. The community service team will act as a facilitator and instructor in training or mentoring, which includes: 1. Explanation of the use and method of making liquid fertilizer from coffee bean skin, 2. Training related to the use of tools and processes for making liquid fertilizer, 3. Monitoring activities after socialization and training. The results of this training and service are that farmers have the ability to make liquid organic fertilizer from coffee bean skin waste expected to increase partners' understanding in processing coffee bean skin waste into liquid fertilizer and adding economic value from coffee bean skin waste so that it has a higher selling value.
\end{abstract}

Keywords: community service, coffee bean skin waste, liquid fertilizer

\section{INTRODUCTION}

Coffee is a popular beverage, made from roasted coffee beans and is one of the commodities that can be found in Jember Regency. The types of coffee which are the main commodities in Jember Regency are Robusta and Arabica. In addition, coffee bean skin is one of the wastes produced in coffee processing and is commonly used as compost, but the majority of unused coffee skin is disposed of and stacked without further use by coffee farmers. The rapid development of the coffee industry is not followed by the maximum handling of post-harvest coffee skin waste.

Coffee bean skin is one of the candidates for organic material that might be used as fertilizer. The use of coffee bean skin as fertilizer material will provide multiple benefits. Besides being able to obtain fertilizers that can provide soil fertility, it can also control environmental pollution due to the abundance of coffee bean skin waste. Nutrients from coffee bean skin are 2.98\% N, 45.3\% organic C, 0.018\% P2O5, 2.28\% $\mathrm{K} 2 \mathrm{O}, 1.22 \% \mathrm{CaO}$ and $0.21 \% \mathrm{MgO}$ (Baon et al, 2005).

Organic waste can not only be used as compost or solid fertilizer but can also be used as liquid fertilizer. Liquid fertilizer is more easily absorbed by plants because the nutrient content in liquid fertilizer has been decomposed, keeps the soil moist, and can eradicate plant pests. Factors that influence the quality of liquid fertilizer from organic waste are raw materials, microorganisms used in the decomposition process, and the manufacturing process. The quality of liquid fertilizer can be measured by testing the nitrogen, phosphorus, potassium, and $\mathrm{C} / \mathrm{N}$ ratios. The high $\mathrm{C} / \mathrm{N}$ ratio indicates that the liquid fertilizer constituent material has not decomposed completely.

The advantages of liquid organic fertilizer are the use of more efficient volume and easier in terms of giving to plants because it can be given by spraying or watering. Furthermore, compared to liquid inorganic fertilizers, liquid organic fertilizers do not damage the soil and plants even though they are used frequently. This fertilizer also has a binding compound so that 
the fertilizer solution can be directly used by plants (Warasfarm, 2013). In addition, liquid organic fertilizer has the advantage of being able to quickly overcome nutrient deficiency (Afghana, 2011).

Sumber Kembang Kelompok Tani (Farmers Group) is a group of coffee farmers in Sukorambi District. Farmers who are members of this farmer group manage the land owned by Perhutani. Routine activities carried out are nurseries, cultivation, cooperation with companies, to marketing products in the form of ready-to-use ground coffee. The problems experienced by coffee farmer groups are the problems regarding coffee bean skin waste. Coffee bean skin waste is not utilized, disposed of and stacked without further use by coffee farmers.

\section{PROBLEM}

Minister of Agriculture Regulation No.2/Pert./HK.060/2/2006, organic fertilizer is a fertilizer that consists mostly or entirely of organic material derived from the remaining plant or animal that has been engineered in the form of solid or liquid which is useful for supplying organic matter, improving physical properties, chemistry and soil biology (Directorate of Production Facilities, 2006). Based on the analysis of the situation, the main problem experienced by the Sumber Kembang Kelompok Tani (Farmers Group) as coffee farmers is the use and processing of waste. The Sumber Kembang Kelompok Tani (Farmers Group) wishes to know how to process coffee bean skin waste and increase the economic value of it. Therefore, the priority issue of the Sumber Kembang Kelompok Tani (Farmer Group) in terms of waste processing is the need for knowledge and skills regarding the process of making liquid fertilizer from coffee bean skin waste. The resulting liquid fertilizer can provide soil fertility, it can also reduce environmental pollution due to the abundance of coffee bean skin waste, and increase the economic value of it, so that it can increase the income of coffee farmers themselves. The training conducted for the Sumber Kembang Kelompok Tani (Farmer Group) is expected to encourage the creation of small and medium enterprises in the area, can absorb labor, and develop liquid fertilizer products from coffee bean skin waste.

\section{METHOD}

The community service activity was held in November - December 2018 in the B Building of the Faculty of Engineering and a hall belonging to residents in the Sukorambi area. The tools and materials used in this activity include coffee bean skin, EM4, granulated sugar, water, plastic barrels, spoons, and sacks.

The service activities with Sumber Kembang Kelompok Tani (Farmer Group) partners are based on the results of situation identification, situation analysis, and problems faced by partners. Based on collective bargaining between the community service team and the Sumber Kembang Kelompok Tani (Farmer Group) in an effort to solve the problems, several approaches were taken, namely an understanding of the content of coffee bean skin that can be used for liquid fertilizer, (b) empowerment of coffee bean skin waste as an effort to control environmental pollution. The details of work procedures are to carry out training or mentoring activities, namely (a) explanation of the utilization and method of making liquid fertilizer from coffee bean skin, (b) training related to the use of tools and processes for making liquid fertilizer, (c) monitoring activities. 


\section{RESULTS AND DISCUSSION}

Coffee farmers who are members of coffee farmer groups have been able to make liquid organic fertilizer. But the liquid organic fertilizer that has been made to date is made without a comparison between one component and another component. Coffee farmers make liquid organic fertilizer made from water soaking coffee beans. The water from the soaking coffee beans is then given EM4 and allowed to stand until the stench comes out of the water. Farmers have claimed that the soaked water and mixed EM4 that has been made can be used as liquid organic fertilizer. This is evidenced by the flourishing of plants that have been given the soaking water. Therefore the soaking water is referred to as liquid organic fertilizer by farmers.

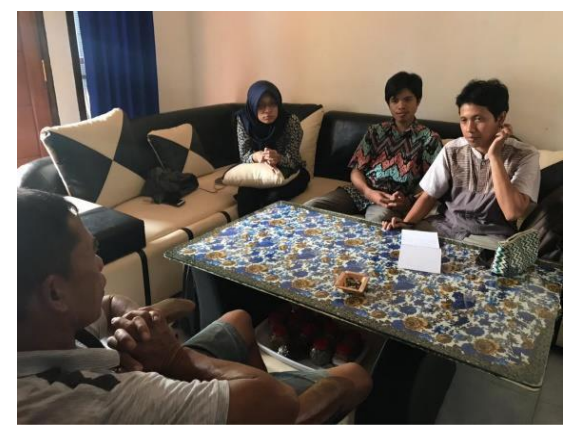

Picture 4.1 Field Survey Activities with the Chairperson of the Sumber Kembang Kelompok Tani (Farmer Group)

(Source: Personal Documentation)

Liquid organic fertilizer made by farmers has not been tested for the compounds needed by plants, namely Nitrogen, P2O5, and K2O. Therefore it is necessary to test the compound content first. The test results of the compound content of the coffee bean soaking water carried out by the team at the Bioscience Laboratory of the Polytechnic of Jember obtained results as shown in table 4.1.

The results presented in table 4.1 show that the compound content in the coffee bean soaking water is still far from the standard liquid organic fertilizer. The standard used is referring to the Minister of Agriculture Regulation No. 70 / Permentan / SR.140 / $10 / 2011$.

Table 4.1 The test results of the compound content of the coffee bean soaking water

\begin{tabular}{|c|l|c|c|c|l|}
\hline No & Jenis Analisa & Satuan & Hasil Analisa & Standar & $\begin{array}{l}\text { Metode } \\
\text { Analisa }\end{array}$ \\
\hline $\mathbf{1}$ & $\begin{array}{l}\text { Nitrogen } \\
\text { Total }\end{array}$ & $\%$ & 0,102 & $3-6$ & $\begin{array}{l}\text { Kjedahl, } \\
\text { Titrimetry }\end{array}$ \\
\hline $\mathbf{2}$ & $\mathrm{P}_{2} \mathrm{O}_{5}$ (Fosfat) & $\%$ & 0,085 & $3-6$ & $\begin{array}{l}\text { Oksidasi } \\
\text { Basah }\end{array}$ \\
\hline $\mathbf{3}$ & $\begin{array}{l}\mathrm{K}_{2} \mathrm{O} \text { (Kalium } \\
\text { Oksida) }\end{array}$ & $\%$ & 0,158 & $3-6$ & $\begin{array}{l}\text { Oksida } \\
\text { Basah }\end{array}$ \\
\hline
\end{tabular}

The activity of making coffee bean skin liquid fertilizer has been carried out and runs smoothly. Liquid organic fertilizer is made together with the Sumber Kembang Kelompok Tani (Farmer Group). In this activity, 2 students from the Jember Chemical Engineering Study Program and coffee farmers joined in the Sumber Kembang Kelompok Tani (Farmer Group) were involved. Liquid organic fertilizer is made using compositions as shown in Table 4.2. 
Table 4.2. Composition of Materials for Making Liquid Organic Fertilizers

\begin{tabular}{|c|l|c|c|c|}
\hline No & \multicolumn{1}{|c|}{ Bahan } & Satuan & Jumlah & Persen \\
\hline 1 & Kulit biji kopi & $\mathrm{kg}$ & 14 & $\pm 30 \%$ \\
\hline 2 & EM4 & $\mathrm{kg}$ & 0,5 & $\pm 1 \%$ \\
\hline 3 & Gula Pasir & $\mathrm{kg}$ & 1 & $\pm 2,1 \%$ \\
\hline 4 & Kapur & $\mathrm{kg}$ & 1 & $\pm 2,1 \%$ \\
\hline 5 & Kotoran Hewan & $\mathrm{kg}$ & 1 & $\pm 2,1 \%$ \\
\hline 6 & Air & $\mathrm{Kg}$ & 30 & $\pm 63 \%$ \\
\hline \multicolumn{2}{|c|}{ Total } & $\mathrm{Kg}$ & 47,5 & $\pm 100 \%$ \\
\hline
\end{tabular}

The procedure for making liquid organic fertilizer through three stages, namely the measurement of raw materials for making liquid organic fertilizer, mixing raw materials, and fermenting the materials that have been mixed. In the measuring process and mixing the raw material for making liquid organic fertilizer, it is done directly by the farmers who are supervised by the service team so that the farmers can practice directly.

The process of mixing liquid organic fertilizer raw materials is carried out in the tub. After the raw material is evenly mixed, it is then put into a sack and put in a barrel filled with water according to the dosage. The process of mixing the ingredients is shown in Picture 4.2.

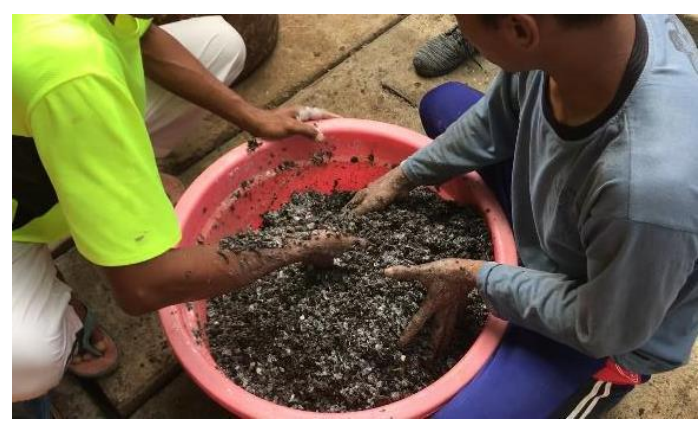

Picture 4.2 The Process of Stirring Liquid Organic Fertilizer Raw Materials

After 10 days of fermentation, the barrel containing liquid organic fertilizer is opened. After being opened and smelled it turned out that the odour caused had a slight smell like Tape. This shows that the fermentation process works and the liquid fertilizer is ready for use. While the remaining fermented coffee beans skin can be used as compost. Fermented liquid organic fertilizer is shown in Picture 4.3.

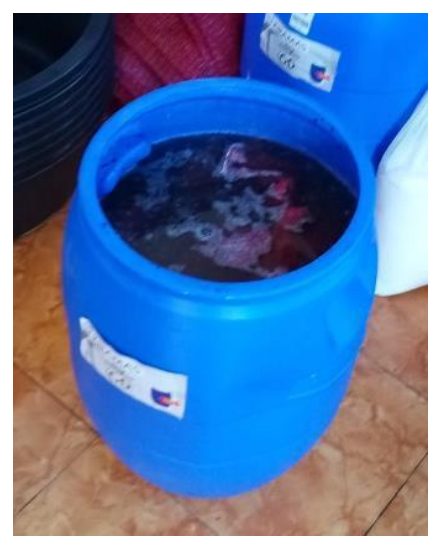

Picture 4.3 Liquid Organic Fertilizer from Coffee Beans Skin 
After this service activity, farmers have been able to make their own liquid organic fertilizer with the composition described. It is intended that coffee bean skin waste is no longer a contributor to environmental pollution.

The conclusions obtained are:

\section{CONCLUSION}

1. Coffee farmers have the ability to make liquid organic fertilizer from fermented coffee beans.

2. Farmers can process coffee bean waste which has been wasted.

\section{THANK-YOU NOTE}

I would like to thank LP2M University of Jember for providing DIPA PNBP funds in 2018 through a community service grant program, the Partnership Service Program.

\section{REFERENCE}

Afghanaus. 2011. Pupuk Organik Cair. http://afghanaus.com/pupuk-organik cair/. Retrieved 7 September 2018.

Baon, J.K., R. Sukasih dan Nurkholis, 2005. Laju Dekomposisi dan Kualitas Kompos Limbah Padat Kopi: Pengaruh Aktivator dan Bahan Baku Kompos. Pelita Perkebunan Vol. 21 No. 1

Direktorat Sarana Produksi, 2006, Pupuk Terdaftar,Direktorat Jenderal Tanaman Pangan, Departemen Pertanian, Jakarta.

Warasfarm. 2013. Potensi Urine Sebagai Pupuk Organik Cair. http: //warasfarm. wordpress .com/ 2013/ 01/ 22/ potensi - urine - sapi - sebagai- pupuk-organik cair -poc/. Retrieved 7 September 2018. 